\title{
Relationship of the cardiac biomarkers with COVID-19: A review
}

\author{
Abdullah Mohammed Abdulkarim \\ Religious Education and Islamic Studies Department, Iraqi Sunni affairs, Iraq (abdroah2015@gmail.com)
}

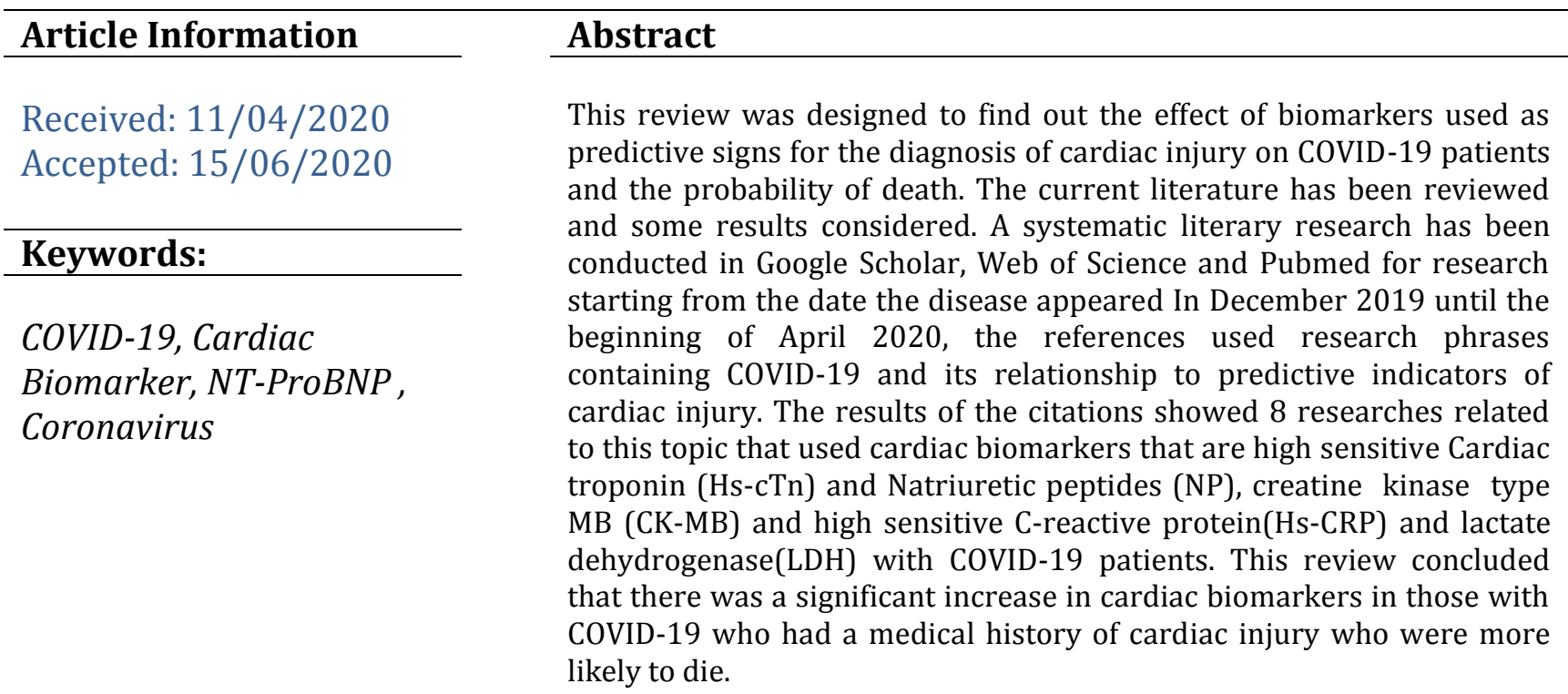

\section{Introduction:}

In December 2019 in Wuhan (Hubei, China), pneumonia came about in a variety of residents of this province for unknown motives however quickly a coronavirus used to be found that reasons extreme acute respiratory syndrome [1].the last time that an emerging global pandemic occurred in the size of the current COVID-19 pandemic without access to appropriate vaccines is an influenza H1N1 pandemic. In this epidemic, the United States and some societies spoke back by means of the use of a set of non-pharmaceutical interventions to decrease transmission and decrease contamination costs and the low loss of life rate, as these measures represented the closure of colleges and church buildings The densely populated locations and these interventions had been early in the epidemic successful, in general, and in most nations throughout the world face the equal assignment to a pandemic COVID -19 [2]. this coronavirus used to be detected on January 6, 2020, and that this virus is successful in infecting human beings known as COVID-19 [3]. As of February 7, 2020, there had been about 43,103 proven instances of COVID-19 with pneumonia in 25 countries [4].It can purpose COVID-19 Acute respiratory misery syndromes, such as acute coronary pneumonia prompted via coronavirus and the Middle East respiratory syndrome [5]. this kind of virus is known as Corona and this disorder has unfolded to the province and has come about many injuries, some of them fatal, and this ailment has to unfold to most of the international locations of the 
world, with greater than 750,000 thousand verified instances recorded with massive numbers of deaths achieving the limits of 38,000 thousand to the duration from the first of the month of April 2020 with the decline in the numbers of damage and deaths in the same province[4].

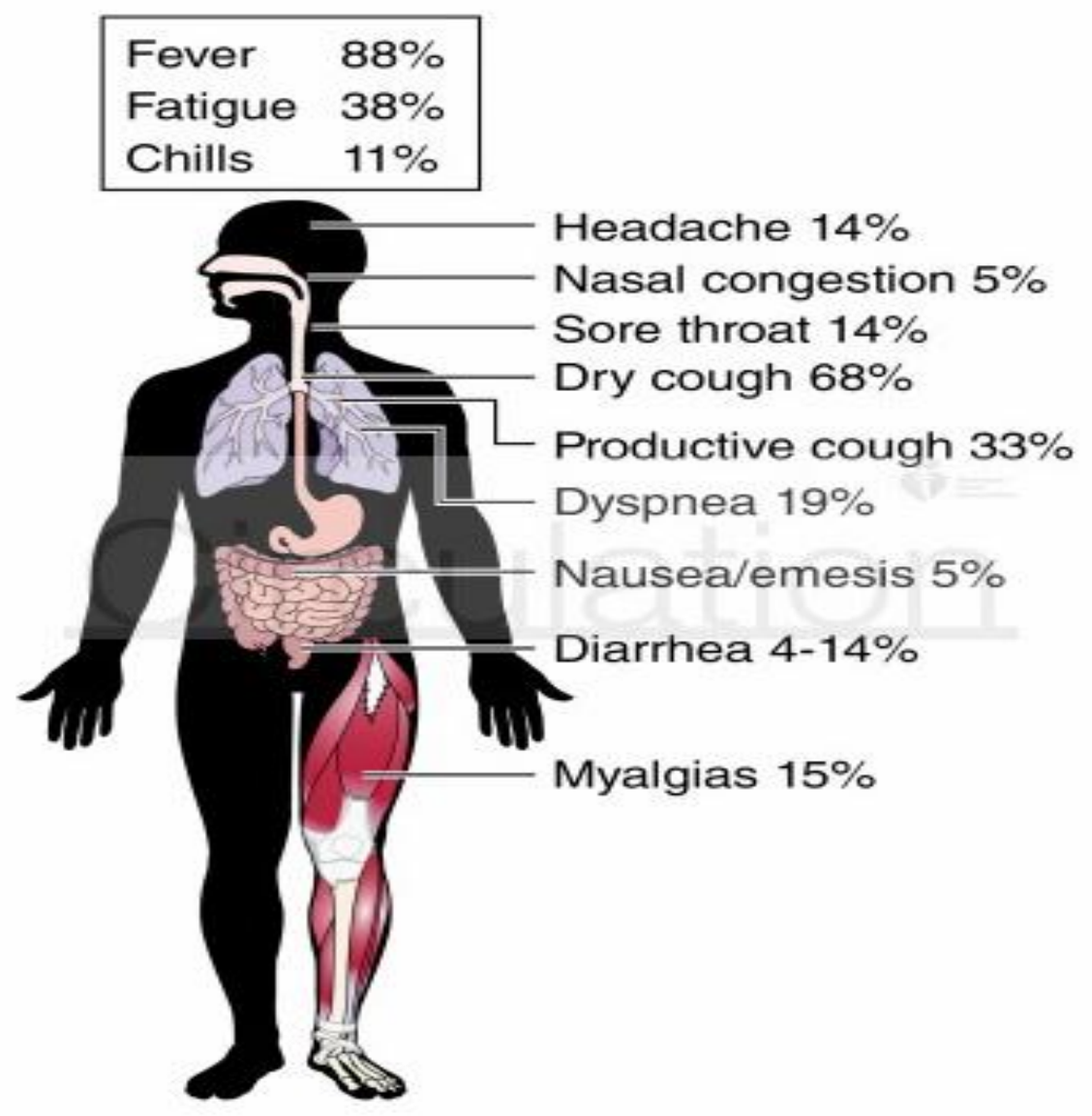

Fig. 1: Symptoms of COVID-19 [5].

Natriuretic peptides are generated specifically inside the cardiac and launched into the circulation in response to rising wall tension, Brain natriuretic peptide (BNP) is solely secreted the ventricles, specifically in sufferers with coronary heart disease [6].each uses $\mathrm{N}$ terminal pro-Brain Natriuretic Peptide (NT-proBNP) and B-type Natriuretic Peptide (BNP) as a beneficial device for scientific evaluation, screening, and prognosis of sufferers with shortness of breath [7].in addition, coronary heart troponins, which are special structural proteins complicated for the heart, are biomarker signs that are specific and sensitive to the heart muscle damage [8].

In this article, some cardiac symptoms have been studied, which are BNP, NT-ProBNP, Troponin I and T (TnI-TnT), excessive sensitivity troponin I (hs-cTnI),High sensitivity CReactive Protein (Hs-CRP), and Creatine Kinase-Muscle Bind (CK-MB) which have been used in current years as important tools for diagnosing risks and speeding decision-making for cardiovascular disease. The reason for this literature evaluate was once to look into and summarize some of the proof that has been concluded about diagnostic equipment used in sufferers with coronary heart sickness and their relationship to infection with coronavirus. The aim of this study is to review the latest literary reviews related to the diagnostic tools 
used for acute heart injury and evaluate the role of these indicators in patients with coronavirus.

\section{Methods}

\section{1-Search Strategy}

Eligible research has been recognized via lookup in the literature and in databases Google Scholar, Web of Science and Pubmed with a center of attention on a range of vital equipment that is used in the analysis of coronary heart sickness and know-how of their relationship with human beings with coronaviruses. Key textual content key phrases had been used as an information advantage and reference chapters COVID-19, NT-ProBNP, BNP and Troponins, CK-MB, Hs-CRP, were examined from all relevant studies and studies were identified potentially relevant missing primary research strategy and statistics covered from December 2019 to April 2020.

\section{2-Study Selection}

Reviewer selected an independent set of studies and the quotations were listed hierarchically according to the title as well as the summary of the research and then the article completely, as well as the differences between the authors as well as resolving the differences between the authors by consensus and that the studies that were included met in a number of criteria are humans, studies assessing cardiac indicators Predictability and its relationship to coronavirus and common biomarker evaluation studies such as troponin, creatine kinase (CK-MB) and myoglobin.

\section{Results}

A digital database has been identified for a set of researches that have been examined and audited through the references and in accordance to the applicable titles that resulted in a variety of researches that have been inside the subject matter title, after a full overview of the articles, which numbered eight studies, as nicely as an assessment find out about of a wide variety of cardiac quintessential indications for human beings with coronavirus, the protected research is proven in Table 1 . The included studies were not homogeneous in the results of a certain number of indicators that were used. In addition, there was homogeneity in a number of variables with each other in those with COVID-19 and most research used in this assessment was once for COVID-19 sufferers who had coronary heart muscle injury. 
Table 1 : Studies evaluating the relationship of cardiac indicators in injury COVID-19

\begin{tabular}{|c|c|c|c|c|c|c|}
\hline $\begin{array}{c}\text { First } \\
\text { author }\end{array}$ & Data time & $\begin{array}{c}\text { Sample } \\
\text { location }\end{array}$ & $\begin{array}{c}\text { Number of } \\
\text { patients }\end{array}$ & $\begin{array}{c}\text { Cardiac } \\
\text { injury \% }\end{array}$ & $\begin{array}{c}\text { Cardiac } \\
\text { biomarker }\end{array}$ & Main result \\
\hline Kevin J [5] & 2020 & $\begin{array}{l}\text { Wuhan, } \\
\text { China }\end{array}$ & 138 & ------- & $\begin{array}{l}\text { hs-cTnI } \\
\text { NT-ProBNP } \\
\text { LDH }\end{array}$ & $\begin{array}{l}\text { A great benefit and with the } \\
\text { passage of days to levels hs-cTnI } \\
\text { in non-surviving patients. }\end{array}$ \\
\hline Tan Guo [9] & $\begin{array}{l}23 / 1 / 2020 \\
\text { to } \\
23 / 2 / 2020\end{array}$ & $\begin{array}{l}\text { Wuhan, } \\
\text { China }\end{array}$ & 187 & $27.8 \%$ & $\begin{array}{l}\text { cTnT } \\
\text { NT-ProBNP } \\
\text { Hs-CRP }\end{array}$ & $\begin{array}{l}\text { It showed high levels of cTnT, } \\
\text { which was positively correlated } \\
\text { with higher levels NT-proBNP } \\
\text { and Hs-CRP. }\end{array}$ \\
\hline $\begin{array}{l}\text { Shaobo Sh } \\
{[10]}\end{array}$ & $\begin{array}{l}20 / 1 / 2020 \\
\text { to } \\
10 / 2 / 2020\end{array}$ & $\begin{array}{l}\text { Wuhan, } \\
\text { China }\end{array}$ & 416 & $19.7 \%$ & $\begin{array}{l}\text { Hs-cTnI } \\
\text { CK-MB } \\
\text { CRP } \\
\text { NT-ProBNP }\end{array}$ & $\begin{array}{l}\text { The death rate for those who } \\
\text { had cardiac injuries was higher } \\
\text { than that for patients without a } \\
\text { heart attack, with a high level of } \\
\text { NT-ProBNP and CRP levels that } \\
\text { were high. }\end{array}$ \\
\hline Xun Li1 [11] & $\begin{array}{l}20 / 12 / 2019 \\
\text { to } \\
13 / 2 / 2020\end{array}$ & $\begin{array}{l}\text { Hubei, } \\
\text { Wuhan, } \\
\text { China }\end{array}$ & 25 & $32 \%$ & $\begin{array}{l}\text { CTnI } \\
\text { LDH } \\
\text { CRP }\end{array}$ & $\begin{array}{l}\text { High levels of cTnI, CRP in patients } \\
\text { with COVID-19 and D-dimer, LDH } \\
\text { can also be used as indicators of } \\
\text { disease progression. }\end{array}$ \\
\hline XIANG, [12] & $\begin{array}{l}29 / 1 / 2020 \\
\text { to } \\
28 / 2 / 2020\end{array}$ & $\begin{array}{l}\text { Zunyi, } \\
\text { China }\end{array}$ & 28 & ------ & $\begin{array}{l}\text { LDH } \\
\text { CK-MB } \\
\text { CRP }\end{array}$ & $\begin{array}{l}\text { The use of LDH to distinguish } \\
\text { severe cases for COVID-19 cases of } \\
\text { moderate COVID-19 and light. }\end{array}$ \\
\hline Chen [13] & $\begin{array}{l}2 / 1 / 2020 \\
\text { to } \\
4 / 2 / 2020\end{array}$ & $\begin{array}{l}\text { Wuhan, } \\
\text { China }\end{array}$ & 150 & -------- & $\begin{array}{l}\text { NT-ProBNP } \\
\text { cTnI } \\
\text { Hs-CRP }\end{array}$ & $\begin{array}{l}\text { NT-ProBNP, cTnI and Hs-CRP } \\
\text { levels increased significantly in } \\
\text { critical patients compared to mild } \\
\text { cases. }\end{array}$ \\
\hline Riccardo [14] & 2020 & $\begin{array}{l}\text { Wuhan, } \\
\text { China }\end{array}$ & 1 & $100 \%$ & $\begin{array}{l}\text { NT-ProBNP } \\
\text { Hs-cTnT } \\
\text { CK-MB } \\
\text { CRP }\end{array}$ & $\begin{array}{l}\text { Higher levels of NT-ProBNP, hs } \\
\text { cTnT and CK-MB and a slight } \\
\text { increase in C-reactive protein } \\
\text { levels. }\end{array}$ \\
\hline Chaomin [15] & $\begin{array}{l}25 / 12 / 2019 \\
\text { to } \\
27 / 1 / 2020\end{array}$ & $\begin{array}{l}\text { Wuhan, } \\
\text { China }\end{array}$ & 188 & ------- & $\begin{array}{l}\text { hs-TNI } \\
\text { CK-MB } \\
\text { LDH }\end{array}$ & $\begin{array}{l}\text { Patients with high levels of cardiac } \\
\text { troponin hs-cTnI have a higher } \\
\text { mortality rate of more than } 50 \% \\
\text { than patients with moderate and } \\
\text { low levels of hs-cTnI. }\end{array}$ \\
\hline
\end{tabular}

The study by Kevin, et al [5], included a wide variety of cardiac indications Hs-cTnI, NTProBNP and Lactate Dehydrogenase (LDH), the myocardial injury was present in $7.2 \%$ of the patients COVID-19 depending on the high levels of hs-cTnI and also 12\% of the patients did not have a heart attack but rather had high levels of troponin highly sensitive, Hs-cTnI levels were above the 99th percentile upper reference limit in $46 \%$ of non-survivors as opposed to $1 \%$ of survivors, the median hs-cTnI amongst survivors did no longer alternate significantly (2.5-4.4 $\mathrm{pg} / \mathrm{ml}$ ) and did not change with the passage of days while there was a significant increase in levels to Hs-cTnI with the passage of days for people who died if recorded24.7 $\mathrm{pg} / \mathrm{mL}$ on Day , to $55.7 \mathrm{pg} / \mathrm{mL}$ on Day 13, to $134.5 \mathrm{pg} / \mathrm{mL}$ on Day 19, and to $290.6 \mathrm{pg} / \mathrm{mL}$ on Day 22 for non-survivors. Notably, the median time to demise from the onset of signs and symptoms was once 18.5 days (IQR 15 - 20 days).in addition to that find out about showed the presence of two types of myocardial harm and are for the lifeless man or woman and survivors, as the study showed that the average levels of highly sensitive troponin in 
survivors were $8.8 \mathrm{pg} / \mathrm{ml}$ in contrast to no- survivors, where the average levels of Hs-cTnI were $2.5 \mathrm{pg} / \mathrm{ml}$ also, the study recorded the rise in the levels of LDH as properly as excessive tiers of NT-ProBNP greater than $21,000 \mathrm{pg} / \mathrm{ml}$.

A study by Tao Guo, et al [9], that myocardial injury is associated with the lethal effects of COVID-19. The find out about confirmed high ranges of cTnT in sufferers with coronaviruses who had previous cardiac defects such as coronary artery disorder and cardiomyopathy in contrast to human beings barring cardiac injuries, Plasma TnT levels verified an excessive and extensively positive linear correlation with plasma hs-CRP levels $(\beta=0.530, \mathrm{P}<.001)$ and NTproBNP levels $(\beta=0.613, \mathrm{P}<.001)$. Plasma TnT and NT-proBNP during hospitalization median, 0.307 [0.094-0.600]; 1902.00 [728.35-8100.00]) and impending loss of life that median 0.141 [0.058-0.860]; 5375 [1179.50-25695.25]) accelerated appreciably in contrast with admission values median, 0.0355 [0.015-0.102]; 796.90 [401.93-1742.25] in patients who died $(\mathrm{P}=.001 ; \mathrm{P}<.001)$, while no significant dynamic changes of TnT median, 0.010 [0.007-0.019]; 0.013 [0.007-0.022]; 0.011 [0.007-0.016] and NT-proBNP median 352.20 [174.70-636.70]; 433.80 [155.80-1272.60]; 145.40 [63.4-526.50]) was found in survivors.. for sufferers with on the whole cardiac injury, median Hs-CRP was once 8.55(4.87-15.16) drastically excessive stages of NT-ProBNP for sufferers at some point of treatment and who finally died. also, Increase levels of NT-ProBNP and malignant arrhythmias have been more frequent in sufferers with increased cTnT.

The studying by Shaobo Sh, et al [10], It confirmed a very large amplify in the range of cardiac indications CRP, CK-MB, Hs-cTnI and NT-ProBNP in sufferers with COVID-19 who had a heart attack compared to patients who did not have coronary heart harm as the median for each of the cardiac indicators who had a heart damage evaluation of those barring cardiac damage that had higher levels of C-reactive protein that median 10.2 [6.4-17.0] vs 3.7 [1.0$7.3] \mathrm{mg} / \mathrm{dl}$, CK-MB that median 3.2 [1.8-6.2] vs 0.9 [0.6-1.3] ng/ml, hs-cTnI median, 0.19 [0.08-1.12] vs. $<0.006[<0.006-0.009] \mu \mathrm{g} / \mathrm{l}$ and NT-ProBNP levels median was 1689 [6983327] vs. 139 [51-335] pg/ml, AST median, 40 [27-60] vs. 29 [21-40] U/L. greater proportions of patients with cardiac injury required noninvasive mechanical ventilation than those without cardiac injury. they find out about additionally showed that the loss of life fee for sufferers who had heart assaults was once $51.2 \%$ compared to $4.5 \%$ in sufferers who didn't have a heart injury.

A study by Xun Li1, et al [11], indicated that death COVID-19 infection occurred with age and underlying diseases have been the most vital chance elements for loss of life and the proportion of people with heart illnesses associated with coronavirus used to be $32 \%$. The study additionally showed an enlarge in CRP ranges in most patients, and the proportion used to be $90.5 \%(21 / 19)$ and find out about additionally recorded an increase in The ranges of cTnI elevated by $88.9 \%$ (9/8) and the share of LDH index was $100 \%$ (9/9). The study finding additionally indicated that the most detrimental organ that falls outside the lungs is the heart and that weakness and dysfunction in each the heart and lung is the reason for The biggest dying for those contaminated with Coronavirus.

A study showed Jialin Xiang, et al [12], statistically big variations in LDH levels at the probability level $(P<0.05)$ between two acute and moderate COVID-19 instances and the 
study showed confirmed that most biochemical markers in the blood, including CK-MB, AST did not show significant differences variations between sufferers with severe and mild COVID-19 and biomarker dispersal In both acute and normal patients, there used to be no difference in serum CRP concentrations in each acute and moderate cases of COVID-19 due to the presence of high ranges of CRP serum in each cases.

In the study by Chen, et al [13], the relationship of NT-ProBNP, cTnI and Hs-CRP biomarkers used to be correlated with COVID-19 infection severity, In this study 126 instances of COVID-19 and 24 cases had been in integral condition and the consequences of the find out about confirmed an enlarge in levels NT-ProBNP, cTnI and Hs-CRP in sufferers with indispensable care instances compared to moderate instances at the probability level $\mathrm{P}$ $<0.05$. Multivariate logistic regression analysis showed that elevated cTnI(OR=26.909, 95\%CI 4.086-177.226, $\mathrm{P}=0.001$ ) and CHD (OR=16.609, 95\%CI 2.288-120.577, $\mathrm{P}=0.005)$ were the independent risk factors of critical disease status. This find out about concluded that COVID19 drastically impacts coronary heart feature and reasons coronary heart muscle injury, and the study showed that patients with a history a former medical practitioner for coronary heart disease and an increase in the levels of cardiac troponin I the independent determinants of the clinical situation of patients those who suffer from COVID-19.

The predominant objective of the study by Riccardo, et al [14], was once to become aware of coronary heart injury with high levels of NT-ProBNP and excessive sensitivity troponin hscTnT as high levels of heart troponin and NT-ProBNP has been detected and that these effects were steady with acute myocarditis and viewed coronary heart injury as issues related with COVID -19 The outcomes of the study reached high levels of signs of cardiac necrosis and the tiers were hs-cTnT $0.24 \mathrm{ng} / \mathrm{ml}$ and an upward jostle in the stages of each CK-MB and NTProBNP as it reached $39.9 \mathrm{ng} / \mathrm{ml}, 5647 \mathrm{pg} / \mathrm{ml}$ on respectively, there used to be a moderate increase in CRP stages $1.3 \mathrm{mg} / \mathrm{dl}$, and with the passage of days, there have been will increase in the studied biomarkers.

The study by Chaomin, et al [15], evaluating the correlations between cardiac damage and demise markers in COVID-19 patients, which indicated 11.2\%, Increased hs-cTnI level on admission tended to occur in older patients and patients with comorbidity (especially hypertension). High hs-TnI on admission ( $\geq 6.126 \mathrm{pg} / \mathrm{mL}$ ) and High CK-MB on admission were associated with higher mortality. High CK-MB was associated with increased inflammatory levels and decreased lymphocytes with COVID-19, the study found that the hscTnI level on admission used to be negatively correlated with survival days $(\mathrm{r}=-0.42,95 \% \mathrm{CI}=$ $-0.64 \sim-0.12, \mathrm{P}=0.005$ ) and LDH level on admission too used to be negatively correlated with survival days $(\mathrm{r}=-0.35,95 \% \mathrm{CI}=-0.59 \sim-0.05, \mathrm{P}=0.022)$. It also established that excessive ranges of $\mathrm{CK}-\mathrm{MB}$, hs-cTnI, and $\mathrm{LDH}$ had been additionally associated with aging diseases, hypertensive patients, and smokers.

\section{Discussion}

The evaluation process for suffering from the coronavirus pandemic stays a diagnostic challenge. Most patients with a range of special risks include coronary heart disease, excessive blood pressure, and diabetes. The current literature on the relationship between the use of 
biomarkers and predictive markers used in acute cardiac injuries with patients with COVID19 was reviewed.

Results carried out a comprehensive review of a range of literature and related matters from the emergence of infections in Coronavirus from December 2019 until March 2020 A number of studies were chosen relying on the extent of the use of predictive and sensitivity cardiac warning signs in the analysis of COVID-19. There is a set of proof that confirmed that the upward thrust in Levels of essential signs and symptoms in COVID-19 patients who especially have a scientific record of acute heart attacks. However, there are quite a few fundamental markers that have proven beneficial and essential consequences in diagnosing COVID-19, information on the patient's condition, and its association with the duration of his survival.

The result observed that some research used various cardiac indicators and be aware of their position in assessing the health status of sufferers with COVID-19.Some reference [5], [9], [10], [11] used Hs-CRP and CRP, and the amplify in these symptoms all through the inflammatory process, which closely correlated with myocardial injury, is that when COVID19 develops, the viral particles that enter The respiratory mucosa will affect different cells, which may also speed up the response to the cytokine storm, which motives an imbalance in $\mathrm{T}$ helper 1 and $\mathrm{T}$ helper 2 that may additionally make a contribution to heart muscle damage and the release of inflammatory cytokines after contamination may additionally reason a reduction in oxygen supply, decreased blood supply and instability of plaque coronary.

Most people with COVID-19 suffer from shortness of breath and this means that the lung is the first and most common reason and this motivates dysfunction in other physique parts and that the most harmful organs outside the lungs are the heart [11].

Some reference [5], [9], [10], [15] used the biomarkers hs-cTnI and cTnI, which verified that excessive degrees of these indicators correlated negatively with the survival period.most studies had been heterogeneous in terms of the number of blood samples and the use of tests. Based on this systematic review, this reference was once restrained due to the heterogeneity of the methodology amongst the included studies. The center of attention of this assessment was on the relationship of cardiac biomarkers with COVID-19 infection, due to the elevated activity is given This disease is a pandemic, and it is an infectious and risky disease, uncontrolled, and finding vital signs that can be predicted in COVID-19 infection. Using this approach for multiple markers may additionally improve diagnostic sensitivity and recognize the impact of these markers on the survival of sufferers alive or not.

\section{Conclusions}

In sufferers with COVID-19, there is inadequate proof to point out the use of biomarkers with excessive sensitivity for heart harm in sufferers with COVID-19. However, the proof has installed that sufferers with COVID-19 who have a medical history of heart harm have multiplied tiers of cardiac markers. They are greater possibilities to die. Further studies are needed to assess the usefulness of other indicators in prognosis. 


\section{References}

1- Huang, C., Wang, Y., Li, X., Ren, L., Zhao, J., Hu, Y., ... and Cheng, Z. (2020). Clinical features of patients infected with 2019 novel coronavirus in Wuhan, China. The Lancet, 395(10223), 497-506.

2- Ferguson, N., Laydon, D., Nedjati Gilani, G., Imai, N., Ainslie, K., Baguelin, M., ... and Dighe, A. (2020). Report 9: Impact of non-pharmaceutical interventions (NPIs) to reduce COVID19 mortality and healthcare demand.

3- Li, Q., Guan, X., Wu, P., Wang, X., Zhou, L., Tong, Y., ... and Xing, X. (2020). Early transmission dynamics in Wuhan, China, of novel coronavirus-infected pneumonia. New England Journal of Medicine.

4- World Health Organization. (2020). Novel Coronavirus ( 2019-nCoV): situation report, 3.

5- Clerkin, K. J., Fried, J. A., Raikhelkar, J., Sayer, G., Griffin, J. M., Masoumi, A., ... and Schwartz, A. (2020). Coronavirus Disease 2019 (COVID-19) and Cardiovascular Disease. Circulation.

6- Bay, M., Kirk, V., Parner, J., Hassager, C., Nielsen, H., Krogsgaard, K., ... and Aldershvile, J. (2003). NT-proBNP: a new diagnostic screening tool to differentiate between patients with normal and reduced left ventricular systolic function. Heart, 89(2), 150-154.

7- Januzzi, J. L., van Kimmenade, R., Lainchbury, J., Bayes-Genis, A., Ordonez-Llanos, J., Santalo-Bel, M., and Richards, M. (2006). NT-proBNP testing for diagnosis and short-term prognosis in acute destabilized heart failure: an international pooled analysis of 1256 patients: the International Collaborative of NT-proBNP Study. European heart journal, 27(3), 330-337.

8- Reichlin, T., Hochholzer, W., Bassetti, S., Steuer, S., Stelzig, C., Hartwiger, S., ... and Noveanu, M. (2009). Early diagnosis of myocardial infarction with sensitive cardiac troponin assays. New England Journal of Medicine, 361(9), 858-867.

9- Guo, T., Fan, Y., Chen, M., Wu, X., Zhang, L., He, T., ... and Lu, Z. (2020). Cardiovascular implications of fatal outcomes of patients with coronavirus disease 2019 (COVID-19). JAMA cardiology.

10- Shi, S., Qin, M., Shen, B., Cai, Y., Liu, T., Yang, F., ... and Huang, H. (2020). Association of cardiac injury with mortality in hospitalized patients with COVID-19 in Wuhan, China. JAMA cardiology.

11-Li, X., Wang, L., Yan, S., Yang, F., Xiang, L., Zhu, J., ... and Gong, Z. (2020). Clinical characteristics of 25 death cases with COVID-19: a retrospective review of medical records in a single medical center, Wuhan, China. International Journal of Infectious Diseases.

12- XIANG, J., Wen, J., Yuan, X., Xiong, S., Zhou, X., Liu, C., and Min, X. (2020). Potential biochemical markers to identify severe cases among COVID-19 patients. medRxiv. 
13- Chen, C., Yan, J. T., Zhou, N., Zhao, J. P., and Wang, D. W. (2020). Analysis of myocardial injury in patients with COVID-19 and association between concomitant cardiovascular diseases and severity of COVID-19. Zhonghua xin xue guan bing za zhi, 48, E008-E008.

14- Inciardi, R. M., Lupi, L., Zaccone, G., Italia, L., Raffo, M., Tomasoni, D., ... and Maroldi, R. (2020). Cardiac involvement in a patient with coronavirus disease 2019 (COVID-19). JAMA cardiology.

15-Wu, C., Hu, X., Song, J., Du, C., Xu, J., Yang, D., ... and Lang, K. (2020). Heart injury signs are associated with higher and earlier mortality in coronavirus disease 2019 (COVID19). medRxiv. 


$$
\text { علاقة المؤشرات الحيوية القلبية مع كوفيا -19 : مراجعة }
$$

عبدالله محمد عبدالكريم دائرة التعليم الديني و الدراسات الاسلامية، ديوان الوقف السني، العر اق (abdroah2015@gmail.com)

\section{الخلاصة.}

صمدت هذه المراجعة لمعرفة تأثير الواسمات الحيوية المستخدمة كعلامات

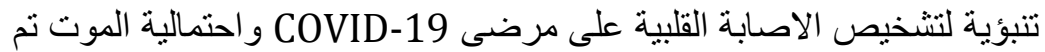
استعراض الادبيات الحالية والنظر في بعض النية النتائج، حيث نم اجراء بحث Google Scholar, Web of Science منهجي أدبي في كل في الادبات Pubmedو للأبحاث ابتداءً من تأريخ ظهور المرض في ديسمبر 2019 وحتى بداية ابريل 2020 وقام المراجع باستخدام العبارات البحنثية التي تحتوبي

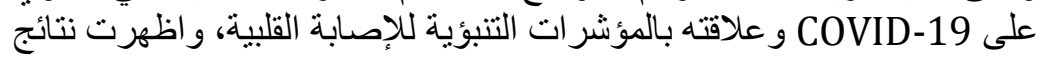

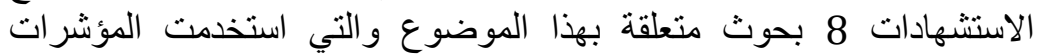
الحيوية القلبية التي هي تروبونين القلب عالي الحساسية والبيتيدات الدماغية

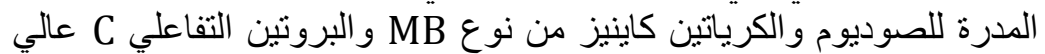

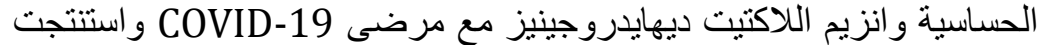
هذه المراجعة وجود ارتفاع كبير في المؤشرات الحئ الحيوية القلبية لدى مصابين COVID-19 و الذين لديهم تاريخ طبي للإصابة قلبية هم اكثر عرضة للئر اللموت.

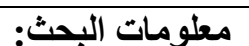

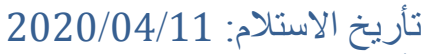

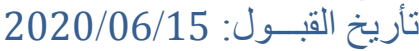

الكلمات المفتاحية:

كوفبد-19، المؤشرات الحبية القلبية،

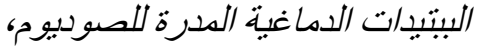
فايروس التاجي 